\title{
TEMPORAL OCCURRENCE PATTERN OF INSECT PESTS AND FUNGAL PATHOGENS IN YOUNG TASMANIAN PLANTATIONS OF EUCALYPTUS GLOBULUS LABILL. AND E. NITENS MAIDEN
}

\author{
by D. W. de Little, S. D. Foster and T. L. Hingston \\ (with four text-figures, four plates and two tables)
}

de Little, D.W., Foster, S.D. \& Hingston, T.L. 2008 (28:xi): Temporal occurrence pattern of insect pests and fungal pathogens in young Tasmanian plantations of Eucalyptus globulus Labill. and E. nitens Maiden. Papers and Proceedings of the Royal Society of Tasmania 142(2): 61-70. https://doi.org/10.26749/rstpp.142.2.61 ISSN 0080-4703. Forest Health Consultant, PO Box 2009, Lower Sandy Bay, Tasmania 7005, Australia (DWdL*); Tasmanian Institute for Agricultural Research, New Town Researçh Laboratories, $13 \mathrm{St}$ Johns Avenue, New Town, Tasmania 7008, Australia (SDF); 2 Laurel Place, Ulverstone, Tasmania 7315, Australia (TLH). * Author for correspondence. Email: dde64113@bigpond.net.au

The occurrence and distribution with respect to plantation age, of insect pests and fungal pathogens were studied over a five-year period in Tasmanian plantations of the native eucalypt, Eucalyptus globulus Labill., and the introduced E. nitens Maiden. A total of 45 taxa of pests and pathogens were identified either by their presence, or by their symptoms, from 289 plantation visits distributed in the north and southeast of the island. Thirty-five taxa were identified on each plantation species. The three taxa, Chrysomelinae, Mycosphaerella spp., and Mnesampela privata were the three most commonly encountered taxa on each host eucalypt species. Other commonly encountered taxa were Acrocercops laciniella, Gonipterus scutellatus, Phaeothyrolium microthyrioides, and Uraba lugens. Some taxa showed a preference for one or other host eucalypt species while other taxa showed no preference. Some taxa preferred younger plantations, while others were more abundant in older plantations. This plantation age-linked distribution is discussed in relation to foliage phase change in the two host eucalypt species.

Key Words: insect pests, fungal pathogens, eucalypt plantations, Tasmania, Eucalyptus nitens, Eucalyptus globulus.

\section{INTRODUCTION}

The establishment of eucalypt plantations began in Tasmania in the late 1970s as an alternative source of fibre and solid wood to native forests (Tibbits 1986). After experimentation with several species, the two main species selected for plantation establishment were the native Tasmanian species, Eucalyptus globulus Labill., Tasmanian Blue Gum, and the mainland Australian species Eucalyptus nitens Maiden, Shining Gum, a native of Victoria and New South Wales. Plantation establishment with these two species has expanded to the point where there are now in excess of 150000 ha in Tasmania (National Forest Inventory 2005). Harvesting of these plantations commenced in the 1990s and many plantations are now in their second rotation.

Land available for plantation establishment in Tasmania lies between sea level and about $700 \mathrm{~m}$ elevation in regions that receive a regular rainfall of greater than $600 \mathrm{~mm}$ per annum. E. globulus is less cold hardy than E. nitens and it is therefore generally established in warmer sites where heavy frost does not occur. As a Tasmanian native tree species it could be expected that E. globulus plantations would be attacked by the insect pests and fungal pathogens that attack the species in native regrowth forests. Outbreaks of pests and diseases in Tasmanian eucalypt plantations led to the development of plantation health surveillance programs in the late 1990s (de Little 2002, Stone et al. 2003, Carnegie, 2007a, b, 2008).

Both eucalypt species exhibit strong heterophylly with foliage phase change occurring in the early years of the plantation cycle. Observations on pest and disease outbreaks suggested that some might favour juvenile foliage or plantations before canopy closure, while others favoured older plantations post canopy closure and with adult foliage. Predictable temporal variations in pest and disease occurrence could enable more efficient monitoring programs.

The current study reports on insect pests and fungal pathogens encountered in Tasmanian E. globulus and E. nitens plantations managed by Gunns Limited (formerly North Forest Products) during a five-year plantation health surveillance program between 1998 and 2002.

\section{METHODS}

\section{Survey methods}

The locations of plantations surveyed on the main island of Tasmania are shown in figure 1 .

Plantations were neither thinned nor pruned and typically varied in size from about $10-100$ ha with trees planted at a spacing of approximately $3 \mathrm{~m}^{2}$, giving approximately 1100 trees per ha. Plantation age varied from $1-21$ years old. Each plantation visited was surveyed by driving as much as was possible of the perimeter and access roads and also by walking at least three widely spaced transects into the plantation perpendicular to the access road. Length of transect walked was determined by the rate of acquisition of new pest and disease information for the plantation but rarely exceeded $100 \mathrm{~m}$.

\section{Identification methods}

Pest and disease organisms were identified by visual detection of their direct presence in association with plantation trees and/or through health disorder symptoms observed on the trees. Where it was not possible to identify causal organisms directly in the field, samples and photographs of the organism and/or its damage symptoms were collected. Samples were maintained in cool storage, and forwarded to relevant experts for identification or compared with descriptions and figures 


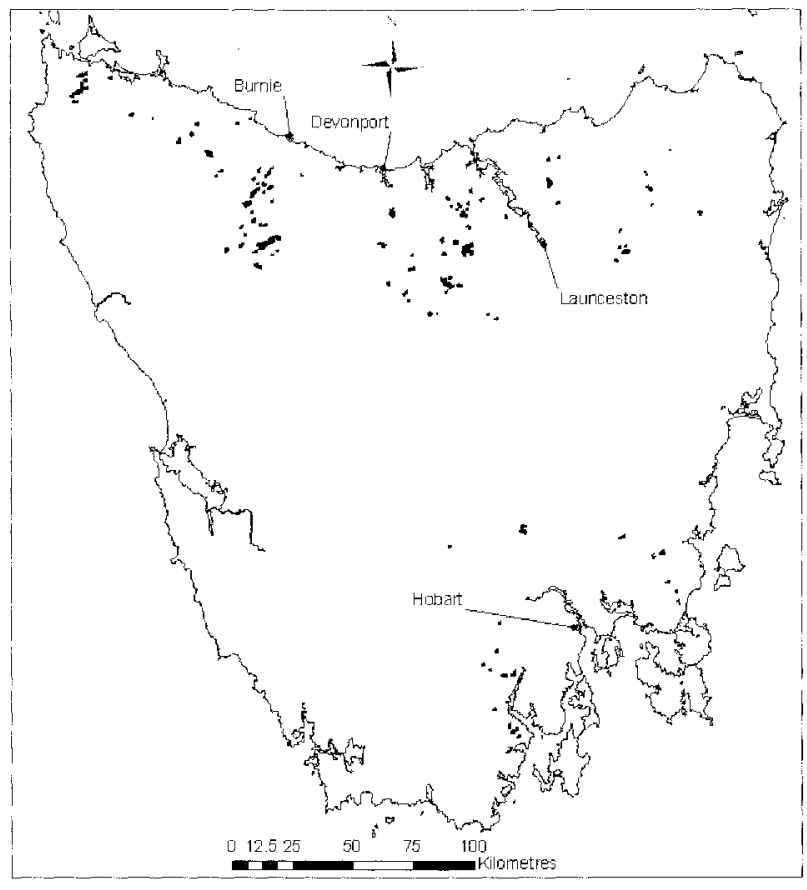

FIG. 1 - Location of plantations within main island of Tasmania.

in the relevant literature (Elliott \& de Little 1984, Elliott $e t$ al. 1998, Keane 2000). In most cases causal organisms were identified to species level, but where this was not possible, identification was to genus, sub-family or family level.

\section{Analysis of data}

Each pest or pathogen taxon was analysed separately using log-linear models (Venables \& Ripley 2002, Agresti 1996) for explaining variation in the number of plantations with damage. Species, year and their interaction were used as possible explanatory variables in the model. Those terms not significant at the $5 \%$ level were removed from the model. A goodness-of-fit test is available for these models. This tests the null hypothesis that the model provides an adequate description of the data, a high p-value in this test indicating that there is no evidence to reject this hypothesis.

This type of model is affected adversely by year and species combinations that have extremely low presence (often zero). For this reason these combinations are excluded from the analysis. This completely excludes some pest/pathogen taxa and some taxa by year combinations. When appropriate, these low values can still be plotted with the results from the formal analysis, but they are not taken into account when interpreting the results.

The data set contained several plantations (approximately $12 \%$ ) that were sampled in more than one year. They were treated as separate plantation sample events for the purpose of analysis.

\section{RESULTS}

\section{Description of plantations}

A total of 289 plantation visits occurred over the five years that the survey was carried out. The age distribution of these plantations is shown in table 1 . Thirty-one plantations were
TABLE 1

Numbers of visits to each age-class of Eucalyptus globulus and $E$. nitens plantations

\begin{tabular}{lccc}
\hline $\begin{array}{l}\text { Plantation } \\
\text { age-class (yrs) }\end{array}$ & Total visits & $\begin{array}{c}\text { E. globulus } \\
\text { visits }\end{array}$ & $\begin{array}{c}\text { E. nitens } \\
\text { visits }\end{array}$ \\
\hline 1 & 46 & 23 & 23 \\
2 & 75 & 30 & 45 \\
3 & 47 & 17 & 30 \\
4 & 32 & 15 & 17 \\
5 & 25 & 5 & 20 \\
6 & 19 & 11 & 8 \\
7 & 17 & 9 & 8 \\
8 & 8 & 3 & 5 \\
9 & 6 & 4 & 2 \\
10 & 3 & 1 & 2 \\
11 & 7 & 1 & 6 \\
13 & 1 & - & 1 \\
15 & 2 & - & 2 \\
21 & 1 & 1 & - \\
Total & 289 & 120 & 169 \\
\hline
\end{tabular}

visited in two separate years during the survey period, and three plantations were visited in three separate years during the survey period.

Plantations ranged in altitude between 10 and $730 \mathrm{~m}$ above sea level. Annual precipitation varied between approximately 800 and $2000 \mathrm{~mm}$ per annum.

Both $E$. nitens and E. globulus exhibit heterophylly, undergoing a change in leaf morphology from juvenile to adult foliage as trees age. The rate of transition from juvenile to adult foliage is presented in figure 2 . The general pattern appears to be similar for both E. nitens and E. globulus plantations but not equivalent $(\mathrm{p}<0.001)$. It appears that the rate of reduction in purely juvenile plantations is similar for both species but the transition rate from mixed plantations to adult plantations is greater for E. globulus.

\section{Pests and pathogens}

Twenty-eight taxa (family to species level) of insect pests and 21 fungal pathogens were identified in the plantations surveyed. These were grouped into insect defoliators (13), insect sap-suckers (8), insect borers (4), insect leaf miners (2), insect gall-formers (1), fungal leaf diseases (17), fungal shoot diseases (1), fungal stem cankers (2) and fungal root diseases (1). Full details are given in table 2 .

Frequency of occurrence varied greatly between pest and pathogen taxa. Some of the pest and pathogen occurrences were relatively evenly distributed between $E$. nitens and $E$. globulus. Several appeared to favour either one or other host species, e.g., Ctenarytaina eucalypti (Maskell, 1890), Ophelimus sp. and Sonderhenia eucalypticola (A.R. Davis) H.J. Swart \& J. Walker on E. globulus, and Amillaria sp., Cadmus australis (Boisduval, 1835) and Heteronyx sp. on E. nitens.

The criteria described in the Methods section for analysis of pest by species by year combinations, allowed four log-linear model analyses to be carried out for four insect defoliators (Chrysomelinae, Mnesampela privata Guenee, 1857, Uraba 
TABLE 2

Taxa of insect pests and fungal pathogens identified on Eucalyptus globulus and E. nitens plantations

\begin{tabular}{|c|c|c|c|c|c|}
\hline Taxon & Type & $\begin{array}{c}\text { Damage } \\
\text { type }\end{array}$ & $\begin{array}{l}\text { Total } \\
\text { records }\end{array}$ & $\begin{array}{l}\text { E. globulus } \\
\text { records }\end{array}$ & $\begin{array}{l}\text { E. nitens } \\
\text { records }\end{array}$ \\
\hline Acrocercops laciniella (Meyrick, 1880) & Insect & Leaf miner & 52 & 23 & 29 \\
\hline Anoplognathus suturalis Boisduval, 1835 & Insect & Defoliator & 2 & - & 2 \\
\hline Armillaria sp. & Fungus & Root disease & 15 & 1 & 14 \\
\hline Aulographina eucalypti (Cooke \& Mass.) Arx \& E. Müll. & Fungus & Leaf disease & 2 & 1 & 1 \\
\hline $\begin{array}{l}\text { Botryosphaeria dothidea (Mougeot ex. EM Fries) Cesati \& de } \\
\text { Notaris }\end{array}$ & Fungus & Stem canker & 1 & - & 1 \\
\hline Botryosphaeria eucalyptorum Crous, H. Smith \& M.J. Wingf. & Fungus & Leaf disease & 2 & 2 & - \\
\hline Botrytis cinerea Pers. & Fungus & Shoot disease & 1 & 1 & - \\
\hline Cadmus australis (Boisduval, 1835) & Insect & Defoliator & 12 & - & 12 \\
\hline Cardiaspina spinifera (Froggatt, 1923) & Insect & Sap sucker & 3 & 1 & 2 \\
\hline Cardiaspina squamula Taylor, 1962 & Insect & Sap sucker & 1 & - & 1 \\
\hline Chrysomelinae (Paropsis spp., Paropsisterna spp., Trachymela spp.) & lnsect & Defoliator & 110 & 36 & 74 \\
\hline $\begin{array}{l}\text { Coreidae (Amorbus obscuricornis (Westwood, 1842) \& Gelonus } \\
\text { tasmanicus (Le Guillou, 1841)) }\end{array}$ & Insect & Sap sucker & 21 & 1 & 20 \\
\hline Cryptosporiopsis eucalypti Sankaran \& B. Sutton & Fungus & Stem canker & 3 & - & 3 \\
\hline Ctenarytaina eucalypti (Maskell, 1890) & Insect & Sap sucker & 15 & 10 & 5 \\
\hline Cylindrotrichum sp. & Fungus & Leaf disease & 2 & 1 & 1 \\
\hline Doratifera pinguis (Walker, 1855) & Insect & Defoliator & 1 & 1 & - \\
\hline Eriococcus confusus Maskell, 1892 & Insect & Sap sucker & 7 & - & 7 \\
\hline Eriococcus irregularis Froggatt, 1921 & Insect & Sap sucker & 1 & - & 1 \\
\hline Fairmaniella leprosa (Fairm.) Petr. \& Syd. & Fungus & Leaf disease & 1 & - & 1 \\
\hline Glycaspis sp. & Insect & Sap sucker & 4 & 3 & 1 \\
\hline Gonipterus scutellatus Gyllenhal, 1833 & Insect & Defoliator & 28 & 26 & 3 \\
\hline Hesthesis cingulata (Kirby, 1818) & Insect & Borer & 3 & 3 & - \\
\hline Heteronyx spp. & Insect & Defoliator & 23 & 2 & 21 \\
\hline Hyalinaspis subfasciata (Erichson, 1842) & Insect & Sap sucker & 1 & - & 1 \\
\hline Lamprima aurata Latreille, 1817 & Insect & Defoliator & 1 & - & 1 \\
\hline Microsphaeropsis sp. & Fungus & Leaf Disease & 1 & - & 1 \\
\hline Mnesampela privata (Guenée, 1857) & Insect & Defoliator & 75 & 25 & 50 \\
\hline Mycosphaerella spp. & Fungus & Leaf disease & 75 & 38 & 37 \\
\hline Myllorhinus dentiferus (Boheman 1858) & Insect & Borer & 2 & 2 & - \\
\hline Ophelimus sp. & 1nsect & Gall former & 14 & 14 & - \\
\hline Opodiphthera helena (White, 1843) & Insect & Defoliator & 1 & 1 & - \\
\hline Paralaea beggaria (Guenée, 1857) & Insect & Defoliator & 2 & - & 2 \\
\hline $\begin{array}{l}\text { Pergidae (Perga affinis insularis Riek, I } 961 \& \text { Pseudoperga lewisii } \\
\text { (Westwood, 1837)) }\end{array}$ & Insect & Defoliator & 3 & 2 & 1 \\
\hline $\begin{array}{l}\text { Kirramyces eucalypti (Cooke and Massee) J. Walker, B. Sutton \& } \\
\text { Pascoe }\end{array}$ & Fungus & Leaf disease & 22 & 3 & 19 \\
\hline Phaeothyriolum microthyrioides (G. Winter) H.J. Swart & Fungus & Leaf disease & 51 & 9 & 42 \\
\hline Phoracanthasp. & Insect & Borer & 3 & 1 & 2 \\
\hline Phylacteophaga sp. & Insect & Leaf miner & 1 & 1 & - \\
\hline Pseudocercospora eucalyptorum Crous, M.J. Wingf. \& Marasas & Fungus & Leaf disease & 14 & 4 & 10 \\
\hline Readeriella mirabilis Syd. \& P. Syd. & Fungus & Leaf disease & 1 & 1 & - \\
\hline Rhadinosomus lacordairei Pascoe, 1870 & Insect & Borer & 2 & - & 2 \\
\hline Sonderhenia eucalypticola (A.R. Davis) H.J. Swart \& J. Walker & Fungus & Leaf disease & 13 & 13 & - \\
\hline Sonderhenia eucalyptorum (Hansf.) H.J. Swart \& J. Walker & Fungus & Leaf disease & 4 & 4 & - \\
\hline Thyrinula eucalypti (Cooke \& Massee) H.J. Swart* & Fungus & Leaf disease & 7 & 3 & 4 \\
\hline Tortricidae & Insect & Defoliator & 12 & 10 & 2 \\
\hline Uraba lugens Walker, 1863 & Insect & Defoliator & 34 & 17 & 17 \\
\hline
\end{tabular}

* Thyrinula eucalypti is the anamorph of Aulographina eucalypti. 

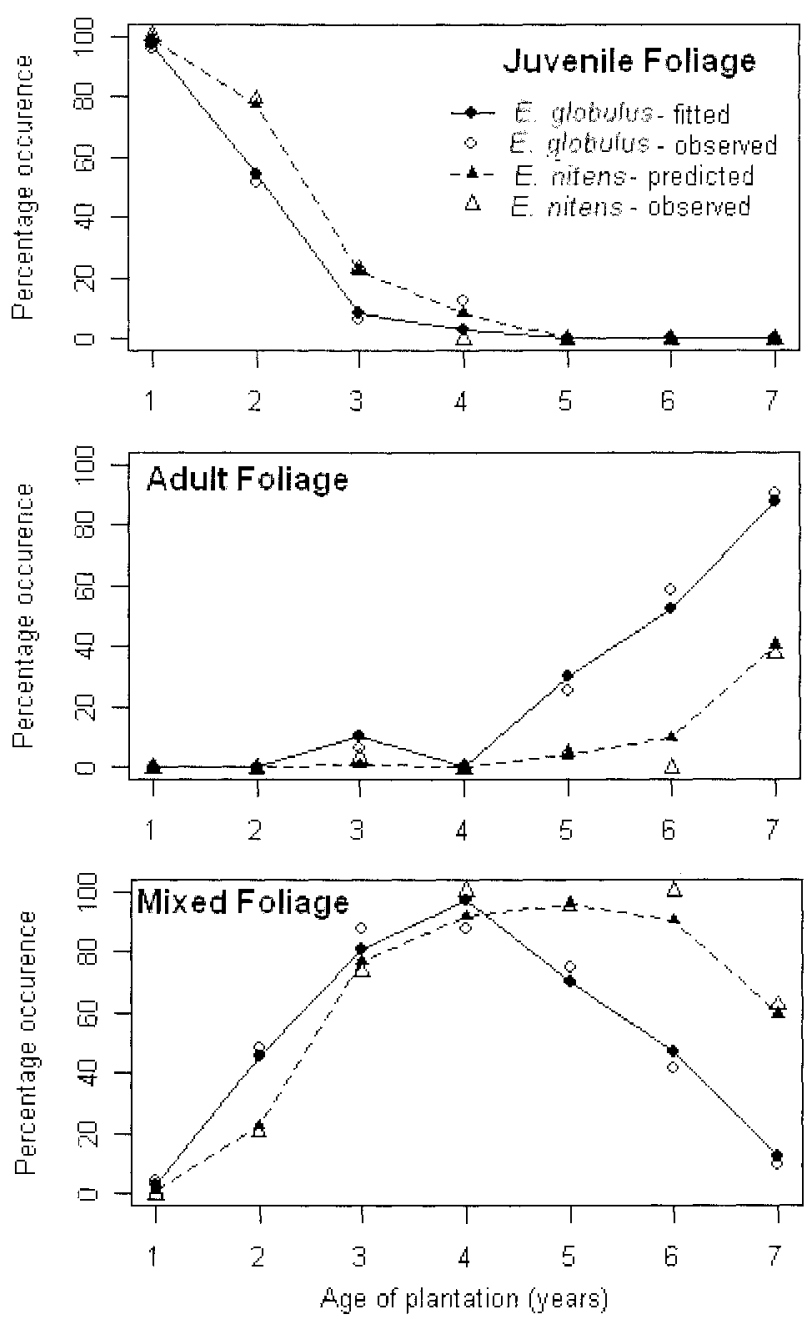

FIG. 2 - Percentage occurrence of plantation foliage types of Eucalyptus globulus and $\mathrm{E}$. nitens at ages from $1-7$ years $(p=0.610)$.

lugens Walker, 1863 and Gonipterus scutellatus Gyllenhal, 1833), one insect leaf miner, Acrocercops laciniella (Meyrick, 1880), and two fungal leaf diseases (Mycosphaerella spp. and Phaeothyrolium microthyrioides (G. Winter) H.J. Swart).

\section{Insect defoliators}

The most commonly recorded pest taxon was the defoliating Chrysomelinae, a sub-family of leaf beetles (Chrysomelidae) (pl.1A) containing about 36 eucalypt-defoliating species in Tasmania (de Little 1989), of which Paropsisterna bimaculata (Olivier, 1807) and $P$. agricola (Chapuis, 1877) are the most common species. Chrysomelinae are generally only present on foliage during the warmer months; however, their presence in plantations was identified by their characteristic scalloping defoliation pattern on leaves that can be recognised at any time of the year (Greaves 1966, de Little 1983). Chrysomelinae were recorded throughout the entire spatial and altitudinal range of plantations. Presence of Chrysomelinae was recorded in both E. globulus and E. nitens plantations and there was no evidence of preference for one species of eucalypt over another. There was an age effect on the number of plantations with Chrysomelinae damage $(\mathrm{p}<0.001)$. Young plantations appeared less susceptible than plantations about three years of age and older (fig. 3).
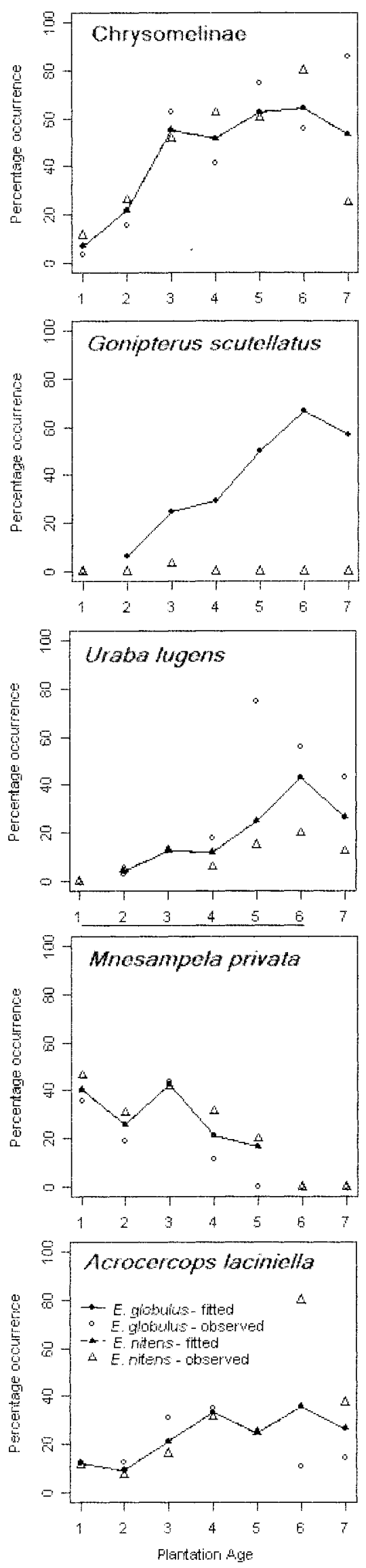

FIG. 3 - Percentage of plantations of Eucalyptus globulus and E. nitens with symptoms of damage caused by Insect Defoliators and Insect Leaf Miners in age classes from $1-7$ years $(p>0.100)$ 
The second most commonly recorded insect pest was Mnesampela privata (Autumn Gum Moth) (pl. 1B). Presence of this pest was detected by occurrence of eggs or egg cases, larvae, or characteristic webbing and defoliation patterns on leaves (Steinbauer et al. 2001). M. privata did not prefer one host species over another but the age of the plantation did affect the incidence $(p=0.037)$. The profile of incidence over time indicates that young plantations have higher incidence than older ones (fig. 3). This finding is consistent with the observation that $M$. privata only attacks juvenile foliage (Steinbauer 2002). M. privata was recorded throughout the entire spatial and altitudinal range of plantations.

Other commonly recorded insect defoliators were Uraba lugens (Gum-leaf Skeletoniser) and Gonipterus scutellatus (Eucalypt Snout Weevil) (pl. 1C, D). Presence of both species changed with plantation age $(p=0.002$ and $p=0.02$ respectively). It was possible to assess the preference of $U$. lugens to plantation type. This test indicated that there is evidence of preference $(p=0.029)$. There were insufficient data on $E$. nitens to perform a similar test for $G$. scutellatus (fig. 3).

Less commonly recorded insect defoliators were Heteronyx spp (Cockchafers), Cadmus australis (Boisduval, 1835) and Tortricidae (Leaf-rollers) (pl. 1E, F, G).

\section{Insect sap-suckers}

The most commonly occurring taxon was Coreidae (pl. 2A), identified by the characteristic damage symptoms of wilted or pruned young shoots. This damage is caused by two species, Amorbus obscuricomis (Westwood, 1842), Gum-tree Bug, and Gelonus tasmanicus (Le Guillou, 1841), Tasmanian Gelonus Bug. Another commonly encountered taxon on very young trees was Ctenarytaina eucalypti, Bluegum psyllid (pl. 2B).

\section{Insect borers}

None of the four insect borers that were encountered was common or widespread.

\section{Insect leaf miners}

Acrocercops laciniella (Blackbutt Leaf-miner) (pl. 2C) was very commonly encountered (mainly in the north of the island) on both eucalypt species. It was recognised by the characteristic "blister" caused by larvae feeding under the leaf epidermis and changed in presence $(p=0.028)$ with increase of plantation age (fig. 3). It appeared to show no preference for either host species.

\section{Insect gall formers}

Ophelimus sp. (Blue-gum Chalcid) was encountered only on E. globulus in a restricted area in the central north of the island. It was recognised by the characteristic galls formed on young shoots (pl. 2D) that led to twisted and distorted trunks and branches in older trees.

\section{Fungal leaf diseases}

The most commonly encountered fungal leaf disease was "Crinkle Leaf" caused by Mycosphaerella spp. (pl. 3A). E. globulus plantations were more susceptible to attack by Mycosphaerella than E. nitens plantations $(\mathrm{p}=0.007)$. Both types of plantations exhibited a significant $(\mathrm{p}<0.001)$ change in incidence over time. Presence appeared to peak in 3-5-year-old plantations, coinciding with maximum quantities of juvenile foliage and the onset of canopy closure and the transition to adult foliage (fig. 4). Carnegie (2007b) observed infection of E. globulus subsp. maidenii by Mycosphaerella nubilosa
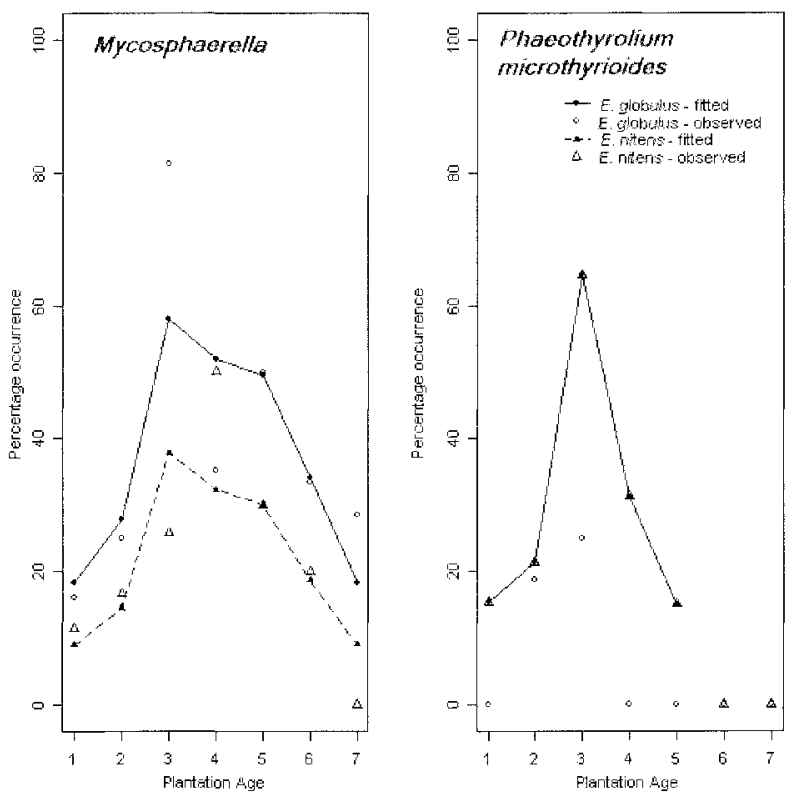

FIG. 4 - Percentage of plantations of Eucalyptus globulus and $\mathrm{E}$. nitens with symptoms of damage caused by leaf diseases in age classes from $1-7$ years $(p>0.05)$.

(Cooke) Hansf. to be highest at age $2-4$ years in several trials in New South Wales.

The second most commonly recorded fungal leaf disease was Phacothyrolium microthyrioides. This species was widespread on juvenile foliage and is recognised by the characteristic "oil blotches" on leaves (pl. 3B). It is much more commonly found on $E$. nitens where its presence changed significantly over time $(p<0.001)$. Presence appeared to peak in three-year-old plantations. The presence of $P$. microthyrioides on eucalypt and Corymbia plantations in New South Wales was recorded by Carnegie $(2007 \mathrm{a}, \mathrm{b})$ although not on either E. globulus or E. nitens.

Other fungal leaf diseases were Kirramyces eucalypti (Cooke \& Massee) J. Walker, B. Sutton \& Pascoe, Pseudocercospora eucalyptorum Crous, M. J. Wingf. \& Marasas and Sonderhenia eucalypticola (A. R. Davis) H. J. Swart \& J. Walker (pl. 3C, D, E).

\section{Root diseases}

Only one root disease, Armillaria sp. (pl. 4), was encountered.

\section{Other fungal pathogens}

Neither shoot diseases nor stem canker diseases were common or widespread.

\section{DISCUSSION}

Many previous studies of individual insect pest and fungal pathogen taxa on Tasmanian eucalypt plantations have been reported in the literature (Bashford 1993, Yuan 1999). This paper represents the first attempt to quantify temporal distribution of these pests and pathogens together in young E. globulus and E. nitens plantations.

The two host eucalypt species are regarded as being closely related taxonomically, both being placed in the series Globulares Blakely (Brooker 2000), but while E. globulus has its main centre of natural distribution in Tasmania, 

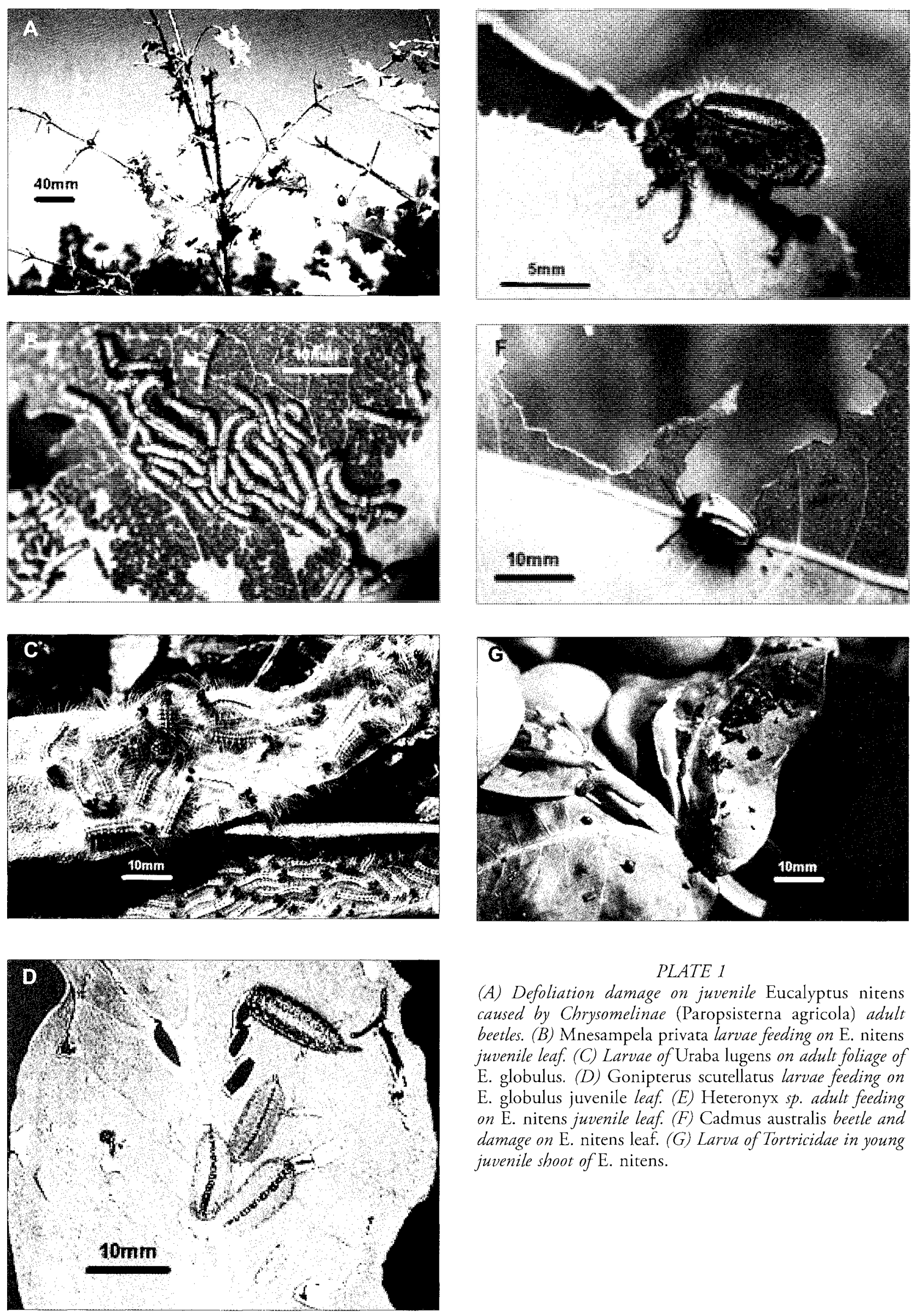

\section{PLATE I}

(A) Defoliation damage on juvenile Eucalyptus nitens caused by Chrysomelinae (Paropsisterna agricola) adult beetles. (B) Mnesampela privata larvae feeding on E. nitens juvenile leaf. (C) Larvae of Uraba lugens on adult foliage of E. globulus. (D) Gonipterus scutellatus larvae feeding on E. globulus juvenile leaf. (E) Heteronyx sp. adult feeding on E. nitens juvenile leaf. $(F)$ Cadmus australis beetle and damage on E. nitens leaf. $(G)$ Larva of Tortricidae in young juvenile shoot of $\mathrm{E}$. nitens. 

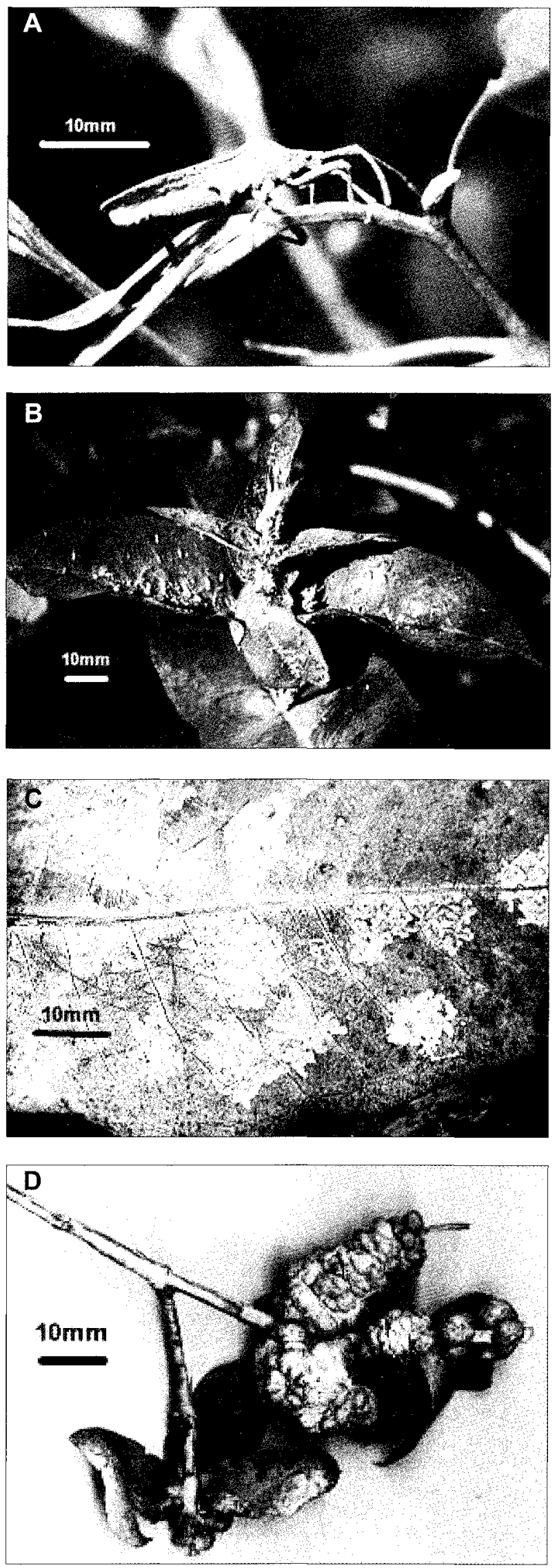

PLATE 2

(A) Coreid bug (Amorbus obscuricornis) on eucalypt shoot (B) Ctenarytaina eucalypti on juvenile foliage of Eucalyptus globulus. (C) Acrocercops laciniella mines on E. nitens leaf. (D) Galls on E. globulus shoot caused by Ophelimus sp.
A

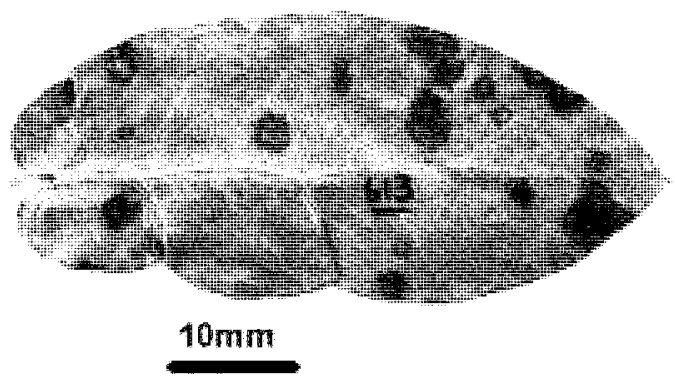

B

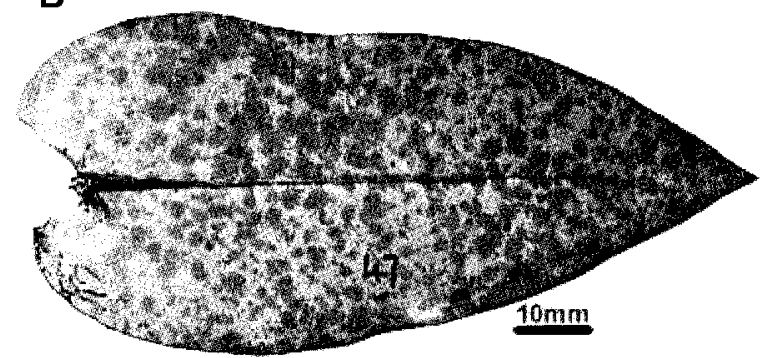

C
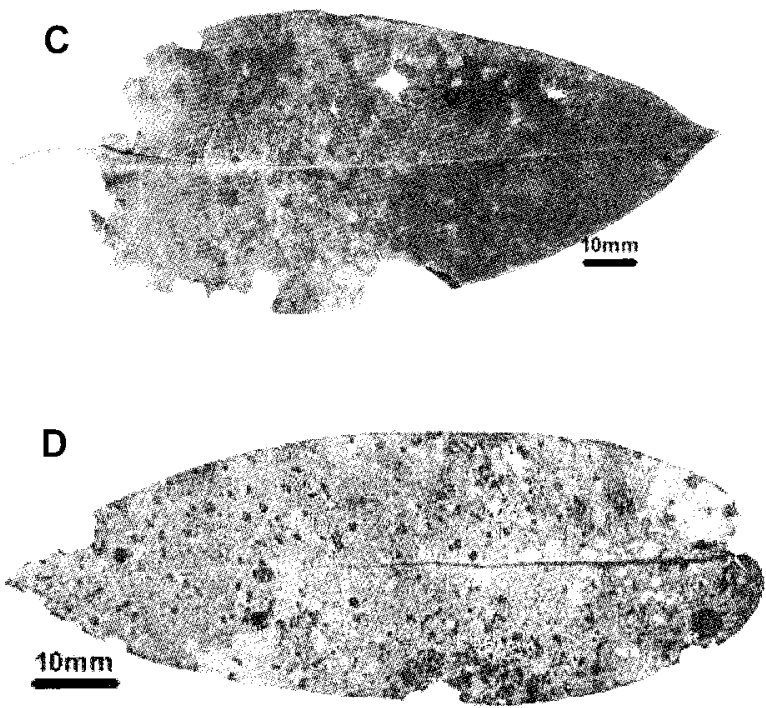

E

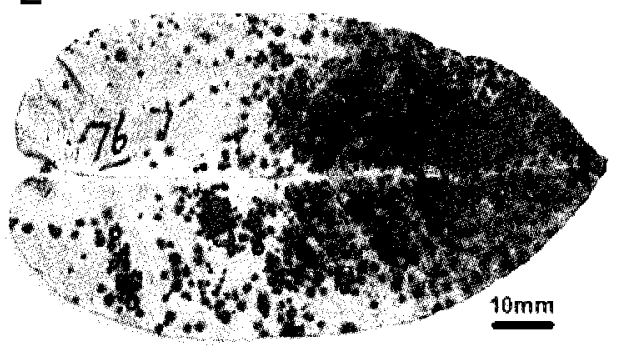

\section{PLATE 3}

(A) Mycosphaerella sp. "Crinkle leaf" lesions on juvenile Eucalyptus nitens leaf. (B) Lesions of Phaeothyrolium microthyrioides on juvenile $\mathrm{E}$. nitens leaf. (C) Lesions of Kirramyces eucalypti on juvenile E. nitens leaf. (D) Lesions of Pseudocercospora eucalyptorum on juvenile E. nitens. (E) Lesions of Sonderhenia eucalypticola on juvenile foliage of $\mathrm{E}$. globulus. 


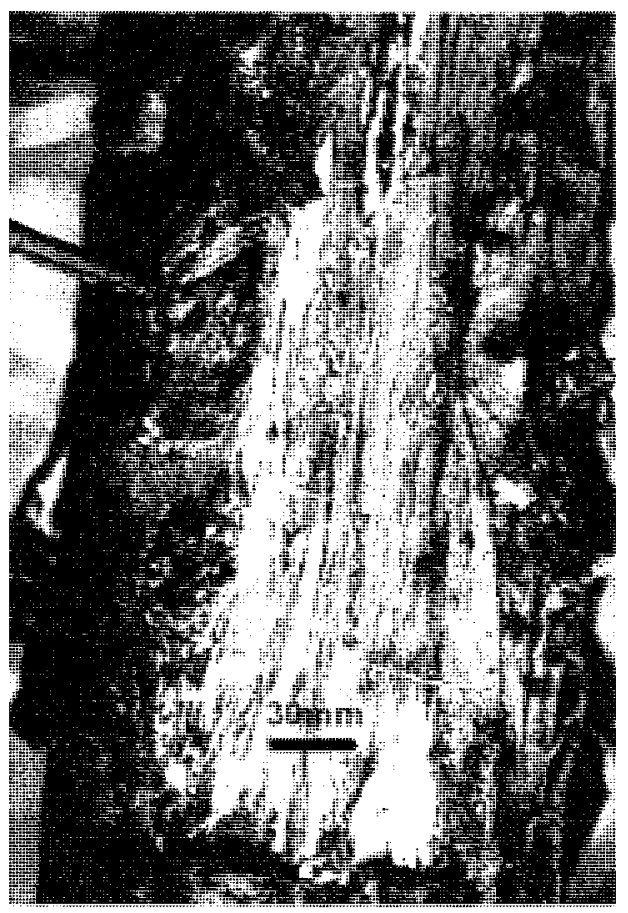

PLATE 4

Armillaria sp. fungal ueft at base of dead eucalypt plantation tree.

E. nitens is an introduced species, occurring naturally in Victoria and New South Wales. At the commencement of this study in 1998, both species had a plantation history of approximately 20 years in Tasmania. Both species exhibit strong heterophylly with the transition to adult foliage exhibiting a similar yet significantly different pattern (fig. 2). The exotic species, E. nitens, was shown to be approximately equivalently susceptible to pest and pathogen attack as its native relative, E. globulus. (table 2, figs 3, 4).

A total of 45 pest/pathogen taxa were identified in this study with approximately $78 \%$ of the taxa occurring on each host. The most commonly encountered pest/pathogen taxa were Chrysomelinae, Mycosphaerella spp., $M$. privata, A. laciniella, P. microthyrioides, $U$. lugens and $G$. scutellatus (table 2). Some of the more common pests/pathogens, while being encountered on both hosts, clearly preferred one host, e.g., P. microthyrioides, E. nitens, $G$. scutellatus, E. globulus.

Attack trends of foliar pests and pathogens with age in plantations up to seven years of age reflected preference for either juvenile or adult foliage. Preference for juvenile foliage was exemplified by $M$. privata (fig. 3). With the fungal leaf parhogens Mycosphaerella spp. and $P$. microthyrioides, there was a build up to a peak at age three to four years as plantation canopies closed creating the moister microclimatic conditions that favour some leaf pathogens. Occurrence then declined as the proportion of more resistant adult foliage increased in the plantations (fig. 4). U. lugens and $G$. scutellatus are examples of pests that build up slowly as the amount of adult foliage increases (fig. 3).

Information provided in this paper will enable managers of Tasmanian eucalypt plantations to improve timing and efficacy of specific insect pest and fungal pathogen monitoring and management programs. For example, monitoring for Chrysomelinae, G. scutellatus and U. lugens need only occur in plantations aged three years or greater, whereas monitoring for $M$. privata need only occur in plantations up to five years old. For Mycosphaerella spp., monitoring need only occur in plantations aged between two and six years.

\section{ACKNOWLEDGEMENTS}

Gunns Limited (formerly North Forest Products) is acknowledged for its support of this work and for the preparation of figure 1 . The authors are grateful to Dr Yuan $\mathrm{Zi}$ Qing (formerly of Cooperative Research Centre for Sustainable Production Forestry) for his identification of many of the leaf pathogenic fungi, Dr John La Salle (Australian National Insect Collection) for his identification of Ophelimus sp., and Mr Dick Bashford (Forestry Tasmania) for his identification of Cardiaspina spp. and Hyalinaspissubfasciata. Drs Christine Stone, GeoffAllen and Humphrey Elliott kindly commented on the manuscript.

\section{REFERENCES}

Agresti, A. 1996: An Introduction to Categorical Data Analysis. Wiley Series in probability and statistics. John Wiley \& Sons, New York: 312 pp.

Bashford, R. 1993: Insect pest problems of eucalypt plantations in Australia. 4. Tasmania. Australian Forestry 56: 375-377.

Brooker, M.I.H. 2000: A new classification of the genus Eucalyptus L'Hér. (Myrtaceae). Australian Systematic Botany 13 $79-148$.

Carnegie, A.J. 2007a: Forest health condition in New South Wales, Australia, 1996-2005. I. Fungi recorded from eucalypt plantations during forest health surveys. Australasian Plant Pathology 36: 213-224.

Carnegie, A.J. 2007b: Forest health condition in New South Wales, Australia, 1996-2005. II. Fungal damage recorded in eucalypt plantations during forest heal th surveys and their management. Australasian Plant Pathology 36: 225-239.

Carnegie, A.J. 2008. A decade of forest health surveillance in Australia: an overview. Australian Forestry 71: 161-163.

de Little, D.W. 1983: Life cycle and aspects of the biology of Tasmanian Eucalyptus Leaf Beetle, Chrysophtharta bimaculata (Olivier) (Coleoptera: Chrysomelidae). Journal of the Australian Entomological Society 22: 15-18.

de Little, D.W. 1989: Paropsine chrysomelid attack on plantations of Eucalyptus nitens in Tasmania. New Zealand Journal of Forestry Science 19: 223-227.

de Little, D. 2002: Forest health - a proactive approach to pest and disease problems in plantations. Australian Forest Grower 25(3) AFG Special Liftout: $6 \mathrm{pp}$.

Elliott H.J. \& de Little, D.W. 1984: Insect Pests of Trees and Timber in Tasmania. Forestry Commission, Hobart: $x+90$ pp.

Elliott, H.J., Ohmart, C.P. \& Wylie, F.R. 1998: Insect Pests of Australian Forests: Ecology and Management. Inkata Press, Melbourne: $214 \mathrm{pp}$.

Greaves, R. 1966: Insect defoliation in the eucalypr regrowth in the Florentine Valley, Tasmania. Appita 19:119-126.

Keane, P.J., Kile, G.A., Podger, F.D. \& Brown, B.N. (eds) 2000 Diseases and Pathogens of Eucalypts. CSIRO Publishing, Melbourne: 616 pp.

National Forest Inventory 2005: National Plantation Inventory 2005 Update. Bureau of Rural Sciences, Canberra: 8 pp.

Steinbauer, M.J. 2002: Oviposition preference and neonate performance of Mnesampela privata in relation to heterophylly in Eucalyptus dunnii and E. globulus. Agricultural and Forest Entomology 4: 245-253.

Steinbauer, M.J., McQuillan, P.B. \& Young, C.J. 2001: Life history and behavioural traits of Mnesampela privata that 
exacerbate population responses to eucalypt plantations: comparisons with Australian and ourbreak species of forest geometrid from the northern-hemisphere. Austral Ecology 26: 525-534.

Stone, C., Wardlaw, T., Floyd, R., Carnegie, A., Wylie, R. \& de Little, D. 2003: Harmonisation of methodologies for the assessment and reporting of forest health in Australia - A starting point. Australian Forestry 66: 233-246.

Tibbits, W.N. 1986: Eucalypt plantations in Tasmania. Australian
Forestry 49: 216-225.

Venables, W.N. \& Ripley, B.D. 2002: Modern Applied Statistics with S. Statistics and Computing. 4th Edition. Springer, New York: xi+495 pp.

Yuan, Zi Qing 1999: Fungi Associated with Diseases Detected During Health Surveys of Eucalypt Plantations in Tasmania: School of Agricultural Science, University of Tasmania: Hobart.

(accepted 26 February 2008) 